\title{
Institutional Strategies To Make Excellent Schools
}

\author{
Cepi Safruddin Abdul Jabar \\ Educational Management \\ Faculty Of Education Universitas Negeri Yogyakarta \\ Yogyakarta, Indonesia \\ cepi_safruddin@uny.ac.id
}

\begin{abstract}
Excellence is another important aspect of achieving school goals. Achievement of excellence involves all school resources in an integrated way with proper management. The objectives of the study is aimed to analyze the institutional strategies of the schools in achieving excellence. Ethnographic research was used to explore the critical efforts of school management that involved three high schools located in Bandung. The phases of this research as follows: 1) Determining ethnographic project, 2) asking questions, 3) data collection, 4) recording of data, 5) data analysis, and 6) writing the report. Data were analyzed using model Spreadley. The results showed that there are three institutional strategies of the school in achieving excellence, such as: 1) Selection of inputs and school staffs; 2) School improvement; 3) Keeping school staff professional; and 3) creating and preserving a culture of excellence.
\end{abstract}

\section{Keywords-Startegies, school effectiveness, excellence}

\section{INTRODUCTION}

A school achieved its excellence by a long continuous process, and focus on its goals. In addition, school excellence also required an integrated effort, involving all components of the school. As a long process, school excellence begins with the preparation process through evaluation[1], integrates all school components, such as curriculum, school staff, parents, and students[2], and focus on goals ranging from achievement, instructional leadership aspects, qualified staff choice, school potential, finance and materials, organizational structure, and school climate[3]

There are three well-known excellent schools as the focus of analysis in this study. A public high school and 2 private high school as follows: SMA Negeri 3 Bandung, SMA Kristen BPK Penabur 1 Bandung, and SMA Terpadu Krida Nusantara Bandung. SMA Negeri 3 Bandung is one of the oldest schools in Bandung. This school was established in 1952 formerly known as Belitung high school because it is located at Belitung Street No. 8. This school is a famous school because of the achievements and inputs of students. Graduates from this school are many who successfully went to the leading universities in Indonesia, especially ITB, UI and UNPAD, every year no less than $99 \%$ of graduates of this school successfully try to public universities (http://www.sman3bdg.sch.id/ En). This school offers regular and acceleration programs.
SMA Kristen BPK 2 Penabur Bandung for the first time held the learning in the academic year 1965-1966 in Kosambi Bandung which then moved to Pasirkaliki street until now (http://smak1bpk.penabur.sch.id/?n=modules/sejarah). In addition to organizing a national program curriculum (Curriculum 2013), the school also offers bilingual national programs, acceleration, and Cambridge International Program (CIP consisting of O-level and A-Level), as well as CIP, blends with the national curriculum.

SMA Terpadu Krida Nusantara founded in 1976 and became the name of SMA Terpadu Krida Nusantara in 1996 (http://smat.kridanusantara.com/index.php/profile-m)

originally. This school implements an integrated curriculum between the regular education and boarding education. This school combines three basic that include science and technology, IMTAQ, and skills based on the character of disciplines in its learning process. The programs offered include regular curriculum programs, religious education, and functional skills.

The single goal of the study was to analize the institutional strategies of the schools in achieving excellence.

\section{METHOD}

The research is a qualitative research. The assumption is that "the method of effective school research is more qualitative than the method of educational production function" [4]. On the other hand, Cohen higlight that effective school research differs from the educational production function in several ways: 1) the study of processes in the classroom and school replaces investigations that focus on static characteristics ... .; And 3) the method shifts from large-scale surveys to in-depth observation and interviews with a small number of schools[4].

Describing this research approach, researchers used ethnographic research methods with case study types (see Cresswel)[5] to uncover efforts to meet excellence by some of the schools categorized as superior by the researchers. The use of ethnographic methods in this study, researchers rely on the assumption that ethnography can be used extensively for various forms of organizations, communities, and disciplines. In fact, contemporary ethnographic methods can be used to 
look at the world of education, public health, rural and urban development, the world of translation and other areas of human life[6].

In determining the sample selection criteria of this study, the researcher used several effective school perspectives which hinted at by some of the experts mentioned in the theoretical study in selecting the unit of analysis. Researchers identified several 'big' schools in Bandung and found three schools that match the standard of contrast desired by researchers, as follows: SMA Negeri 3 Bandung, SMAK 1 BPK PENABUR, and SMAT Krida Nusantara.

Of the three social situations studied, searched data and information related to the focus of research on research subjects who became key informants in this study. As described in Table 3.1. below this:

Table Unit Analysis / Research Subjects

\begin{tabular}{|ll|ll|}
\hline \multicolumn{2}{|c|}{ Units of Analysis } & \multicolumn{2}{|c|}{ Subjects } \\
\hline \hline 1. & SMA Negeri 3 & 1. & Principal \\
Bandung & 2. & Vice Principal - Curr aff. \\
2. & SMA Kristen 1 BPK & Penabur Bandung & Vice Principal - Student aff. \\
3. & MA Terpadu Krida & Vice Principal - Facility \\
& Nusantara & 5. & Heads of Division \\
& 6. & Teachers \\
& 7. & Staffs \\
8. & Students \\
\hline 9. & Parents/Stakeholder \\
\hline
\end{tabular}

This research takes place not linearly, but in the form of cycles in accordance with its characteristics. The various stages, such as data collection, data analysis, and interpretation, simultaneously and repeated. Referring to Spradley's description[7], the research step is cyclical. The cycle includes six steps: (1) choice of ethnographic projects, (2) questioning, (3) data collection, (4) data recording, (5) data analysis, and (6) report writing.

\section{RESULTS AND DISCUSSION}

The excellence that has been achieved, and of course acknowledged by its stakeholders is the result of the efforts of the school a long time ago. It is a deliberate process, a designed process, not a mere coincidence that happens in school. In the achievement of the effort of excellence, there are several efforts made by the school. In this study, it will only focus on institutional strategies, not on other aspects.

To achieve excellence through the institutional dimension, there are several strategies made by the school, as follows.

\section{A. Students and School Staffs Selection}

The selection process for the admission of new students is very important for the successful achievement of educational goals. The suitability of school characteristics with the characteristics of students will greatly determine the effectiveness of the process of learning. Schools will receive or screen students who are expected to offset the pattern of school education. Related to this, the following interview illustrates it.

"We hardly put forward that academic achievement as one of the only requirements for admission of new students. Our goal is to educate, instill values that are the most important and important. Educating the academically ordinary student for outstanding academic achievement is a tremendous challenge that we must face and realize. And most importantly, how to align the academic achievement with the achievement of character education for the students. That's what we always have to remember ".

Schools need students with the same or potential character to compensate for school-based education, training, and care. For that, besides the school academic requirements, physical, and mental is also one of the conditions of admission of new students. Informants stated;

"There is something that is the most important in the selection process for new students, specifically at the end of the selection process. In interview test, the students will be interviewed based on a condition of free of pressure and concealed the result to anyone, including the parents. Asking its ability and want to study in SMAT Krida Nusantara with a condition like this. I often find, there are prospective students who crying, begging not to be passed the selection. Interview test is one of our ways of selecting students who only want to learn with our system. If we do not do this, we will have to deal with students who initially did not want to study here, as there are many parents who expect their children to study here, but their children do not want to.

\section{B. School Improvement}

Efforts to make excellence cannot be done without a solid foundation. To achieve excellence, schools must make internal improvements as a foundation for achieving excellence before making innovations or creating and implementing a policy of achievement efforts. It is including physical environment improvement, improving the staff work system, optimization of human resources, and school culture.

\section{Keeping school staffs professional}

The professionalism of the staff is no less important than the other elements. In achieving excellence, the element of professionalism of teachers received serious attention particularly. Starting from the improvement of educational qualifications, until the mastery of professional knowledge and skills is an absolute requirement for teachers in performing their duties through MGMP or seminars.

In detail, an informant revealed capacity building efforts to keep up professionalism, some of the efforts undertaken by the school, "although not formal, the MGMP in this school is going well". In addition, many teachers attended seminars organized by schools or other parties. The school funded 
teacher participation or holding of a seminar, whether selfhelp participants. Training courses are also being organized for teachers and employees. Currently, language and ICT training is being intensively conducted by schools for teachers associated with efforts to support the RSBI program.

The effort of team teaching with lecturers from various universities is one of the efforts to improve the professionalism of teachers for the mastery of curriculum materials.

In addition, schools also seek to encourage teachers' creative and innovative effort. As stated by informants, "Principals motivate teachers to keep innovating and do their best to make the learning process and student coaching appealing to students, and avoid boredom. ... democratic learning, empowering students by placing students as centers, not teachers. ".

Another way that schools are implemented is to instill the spirit of the "Krida" (though; deed; action; sports), dedication and high loyalty to the school and student education. This "Krida" is expected to continue and to encourage "inner motivation" of teachers and staff in improving their professionalism. And one more important thing, the school emphasizes to all school residents to maintain the code of ethics/honor and educational commitment.

\section{Creating and preserving a culture of excellence.}

The school expected that every activity comes from within, flowing from the heart. Working without coercion, full of consciousness, and high motivation is the dreams of the leaders of their staff. It is recognized by all principals.

Based on findings, there are some points that can be discussed as follow:

\section{A. Students and Staffs Selection}

It takes inputs that have a certain character to be able to achieve excellence effectively, e.g. prospective students can be educated by the school and who can have the potential to be able to adjust to the character and substance of the curriculum. They are expected to have characters relevant to school programs, school culture, and school character. This may not be good for education where education is a basic right of all citizens, whether smart or who have below average academic ability. But such ways are effective enough to make it easier for schools to produce quality output. As revealed in the Baker study, et.al. [8] that student achievement at the previous level significantly influences the success of subsequent studies. Also supported by some subsequent research [9].

As pointed out in the preceding section, it is these traits that become the mode of schools in Indonesia (Perkins, in
Chatib,) [10]. Many schools assume, that garbage in-garbage out. If the input is garbage, then the output remains garbage. This is what becomes a school is not creative, and growing, and dare to make innovations.

Supposedly, excellent schools are schools that are capable of generating enormous educational output from rudimentary student inputs. That is the hallmark of true excellence. This would indicate the character of a super school, "champion school".

\section{B. School Improvement}

School effectivenes is relating to the school improvement. Mentioned by Bollen [1] that that school improvement is aiming at the improvement of the learning process by mentioning explicitly 'learning conditions and other related internal conditions'. The improvements made must be strategic, systematic and well planned. Structuring includes aspects; a) Physical schools (buildings and furnishings); b) Organizational system (organizational structure, work system/mechanism, management); c) Empowerment of human resources: and d) School culture.

Improving school environment is a crucial strategy on achieveing excellence. Fraser [11] indicated that learning is a multiplicative, diminishing-returns function of student age, ability, and motivation; of quality and quantity of instruction; and of the four psychosocial environments - the home, the classroom, the peer group, and the mass media.

\section{Keeping School Staff Professional}

A professional school staff is an absolute requirement of excellence in schools. Increasing teacher capacity is one of the key efforts to keep up professional staff. Recognized in several studies capacity-building has become an effective effort in enhancing the capacity of teaching strategies (4) $\square$, knowledge, skills, and self-confidence (4), supportive leadership, group composition and dynamics, and trust and respect (6) $\square$. For that, the mode that schools do in realizing professionalism in schools, there are several efforts made schools, namely; a) Education and training; b) Empowerment of MGMP/Sanggar; c) Mentoring help from universities; d) Supervision of education; and e) Build spirit, commitment, dedication, and loyalty.

Teacher community play central role in professional development of the school teacher. Vangrieken et.al [12] showed that teacher professional development is everyone owns bussiness. Teacher community - formal formative community teacher, and other stakeholder. 


\section{Creating and preserving a culture of excellence.}

Simply put, culture is translated as the work and creation of human beings institutionalized in a person and many people in an environment. Beach [13] translates simply that culture is something that "... prescribe and proscribe activities, and it defines the "do's and don'ts" that govern the behavior of its members".

From the above definition, we can see that in culture, we will find guidelines and prohibitions on behaving. Furthermore, Beach identifies several cultural components, such as cultural artifacts, uniforms and jargon, rules, and history. Furthermore, Malika [14] states that culture is a symbolic element of organizational life, tangible or intangible, containing the following characteristics:

a) The underlying philosophy and/or ideology espoused by the leaders and members; b) The way in which that philosophy is translated into an operational mission or purpose; c) The respective value-sets of leader and other (both within the organization and those directly or indirectly affected by its operations) and the resonance between these. d) The quality (as well as the nature) of personal and interpersonal actions and interactions; e) The metaphors whis consciously or unconsciously serve as frameworks for thingking and action; f) The sagas, myth, stories, folk heroes and celebrations which serve to generate or bolster incentive and motivation; and g) The many other tangible and intangible manifestation which have hitherto been given scant importance but have both potential and power in the organization. p.10.

Of the seven characteristics of culture, we can summarize that the culture is in the form of ideology or philosophy, and the values (respective value sets) that have the potential and strength as a basis for the activity either consciously or unconsciously.

To achieve excellence, then a long-established culture needs to be identified, whether it supports the achievement of excellence or not? If not or not yet, then create it. Culture is a latent thing that can not be seen and felt, but it can be felt in its impact. It is a powerful driver for individuals to perform well, and create excellence.

Slogans, motto, regulations, uniforms, habits, and norms that exist in the school one form of a culture that can reliably support the achievement of educational goals effectively and excel. In this case, the leadership role in creating, and preserving culture is very important. They are the guardian of culture in order to continue to exist and support the achievement of school goals.

\section{CONCLUSION}

In the context of institutional strategy, there are three common strategies that school use in achieving excellence. First, selection of students and school staffs. School characteristics have suitable with the characteristic of student and school staff will greatly determine the effectiveness of learning. Second, school improvement. The improvement physical environment, staff work system, human resource quality, and school culture. Third, keeping school staffs professional. The that school as such: capacity building, collaborative work with universities in development and team teaching, encouraging staff to be creative and innovative, and the commons values of "Krida".

\section{ACKNOWLEDGMENT}

This project was made possible with support from SMA Negeri 3 Bandung, SMK 1 BPK Penabur Bandung, SMAT Krida Nusantara, and UPI Bandung.

\section{REFERENCES}

[1] D. Reynolds, R. Bollen, B. Creemers, D. Hopkins, L. Stoll, and N Lagerweij, Making Good Schools: Linking School Effectiveness and School Improvement. .

[2] B. McGraww, K. Piper, D. Banks, and E. Beryl, Making Schools More Effective, Report of the Australian Effective Schools Project. Victoria Australia: ACER - Australian Council for Educational Research, 1992.

[3] J. Scheerens, Effective Schooling. Research, Theory, and Practice. New York: Cassell, 1992.

[4] A. Ghozali, "Tinjauan Literatur: Effective School Research," J. Pendidik. dan Kebud., vol. 21, no. V, pp. 58-208, 2000.

[5] J. W. Creswell, Educational Research: Planning, Conducting, and Evaluating Quantitative and Qualitative Research, 4th ed. London: Pearson, 2012.

[6] P. Pardede, "Penelitian Etnografi," 2009. [Online]. Available: http://jojoparlisda.blogspot.co.id/2009/02/penelitian-etnografi.html. [Accessed: 04-Mar-2016].

[7] J. P. Spradley, Participant Observation, vol. 53, no. 9. 1980.

[8] J. Baker, D. Tucker, E. Raynes, F. Aitken, and P. Allen, "Relationship between student selection criteria and learner success for medical dosimetry students," Med. Dosim., vol. 41, no. 1, pp. 75-79, 2016.

[9] L. Lindstrom, Secrecy, Anthropology of, Second Edi., vol. 21. Elsevier, 2015.

[10] M. Chatib, “'BEST PROCESS' - INDIKATOR SEKOLAH UNGGUL," $2008 . \quad$ [Online]. Available: https://munifchatib.wordpress.com/2008/07/29/“best-process"indikator-sekolah-unggul/. [Accessed: 03-Feb-2017].

[11] B. J. Fraser and M. E. Centre, Environments for Education, Second Edi., vol. 7, no. 1991. Elsevier, 2015.

[12] K. Vangrieken, C. Meredith, T. Packer, and E. Kyndt, "Teacher communities as a context for professional development: A systematic review," Teach. Teach. Educ., vol. 61, pp. 47-59, 2017.

[13] B. L.R., Making The Right Decision, Organizational Culture, Vision, and Planning. New Jersey: Prentice Hall, 1993. 
